\title{
The Well- and Unwell-Being of a Child
}

\author{
Christina Schües $\cdot$ Christoph Rehmann-Sutter
}

Published online: 5 May 2013

(C) Springer Science+Business Media Dordrecht 2013

\begin{abstract}
The concept of the 'well-being of the child' (like the 'child's welfare' and 'best interests of the child') has remained underdetermined in legal and ethical texts on the needs and rights of children. As a hypothetical construct that draws attention to the child's long-term welfare, the wellbeing of the child is a broader concept than autonomy and happiness. This paper clarifies some conceptual issues of the well-being of the child from a philosophical point of view. The main question is how well-being could in practice acquire a concrete meaning and content for a particular issue or situation. A phenomenological-hermeneutic research perspective will be outlined that allows the child's well-being to be elucidated and specified as an anthropological and ethical idea. It is based on a contextual understanding of generative relationships, a combination of the theory and practice of making sense, here described as 'generative insight', which could provide ethical guidance for decision making in families, legal practice, medicine or biomedical research.
\end{abstract}

Keywords Child ethics - Well-being ·

Children's well-being - Best interests of the child .

Children's rights · Vulnerability · Care ·

Phenomenological-hermeneutic philosophy

\section{Introduction}

Children's health and flourishing can be infringed in many ways, by human interference, social circumstances, or

C. Schües · C. Rehmann-Sutter $(\square)$

Institute for the History of Medicine and Science Studies,

Königstraße 42, 23552 Lübeck, Germany

e-mail: rehmann@imgwf.uni-luebeck.de

URL: www.imgwf.uni-luebeck.de through natural causes. Cultural traditions and historical eras differ in their understandings of what is special about childhood, of what constitutes the child's special vulnerability, and of the minimum (and optimum) requirements of a child's life. This heterogeneity in the conception and realization of childhood, and the many ways children are exposed to harms or threats, result in varying levels of protection of children's needs. The UN Convention on the Rights of the Child (1989) emphasizes that "In all actions concerning children, whether undertaken by public or private social welfare institutions, courts of law, administrative authorities or legislative bodies, the best interests of the child shall be a primary consideration." (Art. 3.1) It grants children the right to life and development, to a name, to free expression of his/her views, to freedom of thought, conscience and religion, the right not to be illicitly separated from his/her parents, to enjoy the highest attainable standard of health, to an adequate standard of living, to be protected from economic and sexual exploitation, and so on. This legally binding instrument of international law is also an ethical guideline that defines a set of minimum requirements as non-negotiable standards. It strongly emphasizes that children's well-being and best interests should override any other political, social or individual interests and considerations of such authorities or institutions. However, the underlying concept of the 'well-being of a child', or of 'a child's best interests', cannot easily be deduced from such a list of children's rights. Many rights are negative rights and others identify necessary requirements for the child's well-being in a very general sense. But they do not explain the concept of wellbeing itself. There are many possible interpretations, each presuming a vision of good human development that is dependent on a particular and rich cultural understanding of the good life and of human relations. The child's well- 
being and best interests therefore remain vague and are not positively defined in national legislation. ${ }^{1}$

The aim of this paper is to clarify the concept of wellbeing of the child from a philosophical point of view. We shall discuss how it acquires concrete meanings. This requires, furthermore, to understand how it is structurally embedded. A research perspective will be outlined that would allow the child's well-being to be used as a normative idea to guide decision processes and actions within legal, familial, medical, and other contexts.

After a few remarks on terminology (1), we organize the paper around the following questions: What is specific to the concept of well-being concerning children? (2) What can we know about it? That is, how can we as adults gain insight into the concrete and philosophical challenges of the well-being of a child? (3) Which themes and questions are important in general for understanding well-being and what we could call 'unwell-being'? Obvious themes are the 'good life', the quality of the relationships within which the child lives, and justice. Since young children cannot or can only partially make decisions for themselves, the aspect of the child's future becomes more pertinent in evaluating the well-being of a child. How can these temporal dimensions of well-being be articulated? (4)

\section{Terminology}

1. In many but not in all contexts, the terms 'well-being', 'welfare' and 'best interests' of the child can be used interchangeably. Although we do not argue for a systematic distinction between them in this paper, we do point out differences whenever appropriate. Whereas 'well-being' more directly refers to ideas about the 'good life' of a child in a biographical context and emphasizes health and happiness-or disease, impairment, and pain-'welfare' adopts a more societal perspective, emphasizing the primary goods and freedoms, while 'best interests' refers to what is in favor of the individual child over the long-term and emphasizes the claims children would have good reason to make, if they could speak for themselves. It may be more closely related to the Anglo-American tradition of liberalism, focussing especially on the rights of children, the implicit or explicitly uttered interests of the child, the will, and the objective and long-term interests of the child. 'Well-being' and 'best interests' are closely related, however, since to be well must surely be in the

\footnotetext{
${ }^{1}$ Because of its vagueness and indeterminate meaning, Steindorff (1994, 1-6) observes that the well-being of a child is an "empty box"; according to Figdor (2009) it is an unsuitable basis for professional decision-making.
}

child's best interests. Well-being and welfare may be associated to the tradition of Roman law. Well-being concerns both the subjective aspects of feeling well and the objective aspects of care, support, and protection.

2. In many cases, neither well-being per se nor its infringement or neglect seem appropriate to describe the situation. Since the concept of the well-being of a child must remain under-determined, legal or ethical texts instead refer to its counter-term: the endangerment of the child. When a child is physically or emotionally mistreated, abused, or neglected, somebody is clearly acting against his or her well-being, but well-being in the long-term is not rendered impossible. On the other hand, if a child is not endangered, abused, or neglected, it might still not be fully well. Hence, the term 'the well-being of the child' often serves a technical function by pointing out how children should not be treated. The notion of child endangerment hinges upon someone-who has the legal or moral role of adopting a responsible, supportive, caring relation to the child, usually the parents-who is made accountable for endangering the child (cf. Rosenheim et al. 2002).

3. In addition to the rather holistic concepts of well-being and the counter-term child endangerment, we introduce the unwell-being of the child as a specific concept. We say, a child is unwell if she/he is sick, is under duress, in pain or fear, suffers from malnutrition, etc., or is feeling unwell. A child might be acutely unwell but yet one would not speak of endangerment, and a child welfare office would not consider separating the child from the family or caretaking institutions. Examples are abundant: if a family has lost a member by accident, a bereaved child can be acutely unwell but her/his well-being may still not be endangered. In many medical situations, parents face questions of compromise: a child may be acutely unwell as a result of medical treatment, which however is necessary for restoring health or saving its life in the longer term. Well-being and unwell-being are therefore not symmetrical terms.

4. In legal terms, childhood begins with birth and ends at a certain age (18 in most countries). Socially, psychologically, and culturally, the point at which a person ceases to be a child is however ambiguous. The adolescent may in certain respects still be a child, but in other respects already be mature. Legal definitions may set an age limit to childhood but cannot remove this phenomenological complexity. In everyday life we sometimes expand the use of the term beyond any age limit, when we say for instance that we all remain the children of our parents. 
The well-being of the child relates to the physical, mental, personal, cultural and social development which results in a meaningful life with other humans (Schües 2013). Thus, we must think about what children need (their basic needs), what they want (a child's will) and what they are entitled to (children's rights). We also need to see how the basic needs, the child's will and the child's rights are properly addressed and implemented within the family and in the society in which they live. Therefore, a deeper understanding of the child's well-being, and a more precise account of acting in the best interests of children, must rely on a interdisciplinary inquiry that includes philosophical anthropology, ethics, psychology, law, cultural and social studies. This inquiry must be based on the descriptive and the normative dimensions of all aspects relevant to the child's present life, her or his relationships, and future perspectives.

\section{What is Specific to the Concept of Well-Being for Children?}

Current philosophical approaches to well-being explain the notion 'well-being' in general by reference to a list of basic human capabilities, basic needs, to pleasures and pains, or to human desires (Crisp 2008). The latter two approaches determine well-being rather formally and hence cannot point out particulars of the content of children's wellbeing. 'Objective list theories' such as the capability approach (Nussbaum 2011) or the needs or rights of children (Alston et al. 1992) seem more promising because they make the specific contents of children's well-being explicit. However, we argue that such objective lists need to be complemented by an approach to what we call generative relationships.

By generative relationships we mean primarily familial relationships across generations that are constituted through birth, parenting, and education. 'Generativity' or the adjective 'generative' refer to an intersubjective, familial, historical, and socio-cultural process in which a child is born into and lives in the world. Therefore, "generative experiences occur in between generations; therefore, they are always intergenerative" (Schües 2012, 89). The term "generativity" stands for the psychological and social context of becoming, which takes place within a generation and in-between different generations: It is realized in different kinds of relationship, such as parentschild relationships, sibling relationships, or grand-parentschild relationships. Generativity means, secondly, the social and historical process over generations. Thus, it includes different generations and reaches over them. Thirdly, the term generativity stands for the biological or corporeal intertwinement within the family which includes two or three or more generations (Schües 2008; Steinbock 1995; Husserl 1973, 171). Fourthly, as Maurice MerleauPonty has pointed out, generative relationships are the basis for the development of both individuality and personhood in general: "our birth, or [...] 'generativity' is the basis both of our activity or individuality, and our passivity or generality" (Merleau-Ponty 1962, 428; cf. Schües 2008, p. 323ff.).

When we refer to family or to parenthood we are not referring exclusively to those people involved in biological parenthood. An African proverb says: "It takes a village to raise a child." Both the objective and subjective aspects of generative relationships are necessary for the development of personality, as well as for happiness and satisfaction in life. Familial and caring relations are central to the child's flourishing; yet children are also made vulnerable through these very relationships. They are born into relationships and they must cope with their particular features throughout their lives. Most adult relationships include the freedom to end them, should they turn out to be difficult or harmful. Children can rarely change their parental or familial relations of their own choice. If a parental relationship is changed or broken, this would be, rather, due to the choice of adults (e.g. through divorce), or as a consequence of tragic events (e.g. the death of a parent), or in the case of child endangerment, the decision of state authorities.

A phenomenology of generative relationships could start with a list of children's rights as provided by the UN Convention, for example. If children are abused, neglected or beaten, or live in realities of violence, their well-being is endangered or completely absent. An objective (in the sense of being ascribed from a third person perspective) list of the necessary elements of well-being identifies the basic needs of a child that must be both legally and ethically recognized: children are in need of happiness, love, and understanding, stable living conditions and secure familial relations; they need good nutrition and health care, protection and support against physical and social dangers, such as physical or emotional violence, or economic and sexual exploitation; they need knowledge, education, and experience, in order to become a mature individual with selfhood and a social identity, and a responsible member of the community. If some of these needs are not taken care of, are neglected or violated by parents or carers, we speak of child endangerment. However, what all these aspects mean and how they hang together depends on an understanding of the psychological and moral status of a child, the subjective perspectives of the persons involved, the qualities of the child's relationships, and of the situation in its social and cultural contexts.

Several aspects of a list must be based on children's subjective perspectives in order to fully grasp the context and their individual needs. However, since children always 
live in concrete relationships and social contexts, their subjective perspective is already relational, embodied, and specifically situated. Subjectively and objectively, children are in need of supportive and good generative and other social relationships. These are as important to living as water and air.

There is an obvious but important difference between the general concept of well-being, which focuses on mature persons, and the well-being of a child, in terms of the status of autonomy and will. Mature adults are recognized to have the capacity to decide for themselves and to utilize their capacities of autonomous agency. Hence, to respect their dignity, respect for their autonomy is the key. Cases where an adult cannot decide for her- or himself are seen as exceptional and treated as such. Adults are basically free to decide how to look after themselves. An adult may ruin her health, her capacities or her possibilities for development, for instance by drug abuse. ${ }^{2}$ It is part of Western juridical culture to allow this to happen, even if ethically one might not want to approve of it. When it concerns a child, who is considered as being in the phase of immaturity, his/her development are the focus of education in terms of 'cultivation' (Siep 1994, 294). We do not allow children to ruin their development. In most countries, a 12-year-old is not considered free to decide to quit school and to waste her mental capacities. For the sake of its long-term welfare, limits are therefore placed on the will of a child. A similar observation can be made in medical contexts. Children's growing selfhood is considered as a basis for their participation in decisions. In decision-making about treatment, a 12-year-old girl must be heard, she must be allowed to feel respected, but she would need to be very compelling in order to convince her family not to continue a life-saving treatment. Does well-being always essentially include autonomy, or is well-being of the child independent of the child's developing autonomy? As a hint to answering this question we suggest two things: firstly that the well-being of the child includes the acknowledgment of her will relative to her maturity and circumstances; secondly, the child must be given the space and the possibility to develop the capacity for self-determination and autonomy later in life.

For most authors (see references in Hagger 2009, ch. 2; Schickhardt 2012, ch. 6), recognition of the child's own will is part of the well-being of the child. Child psychiatrist Reinhart Lempp said that any will, including that of adults, can easily be influenced. Upbringing and education always exert some influence on the will, and children might even have a right to be influenced. Yet the importance of the will does not change with the child's age, only the way in which it is expressed (Lempp 1983, p. 111). Limits to the will,

\footnotetext{
${ }^{2}$ Health insurance companies or social costs may act as deterrents to maltreating oneself.
}

however, are set where its consequences would endanger well-being (Dettenborn 2010). At this point we go in circles: although the child's will must be recognized and respected, in the name of well-being, if the child expresses a decision that acts against its well-being-from the perspective of the caregiver or responsible third person-then it will be overruled.

If the child is to participate, capacitation is needed. To be capacitated the child needs qualitatively good, supportive relations. Both capacitation and respect for the will of the child are also based on cultural conventions about how to treat children well and how to see childhood. ${ }^{3}$ The aspects we have described as being key for well-being are historically and culturally not universal. As we have formulated them, they grew out of the European tradition of human rights.

Less dependent on cultural premises is the experience of an unwell-being of a child. However, the terms well-being and unwell-being, as we have already said, are asymmetrical: unwell-being means that the child is not feeling well, that it faces a difficult situation, is sick, or is not getting a good education, that life is gray or the family relationships are poor. These things can pass. Most of them do not necessarily harm the long-term well-being of the child. If we think that the well-being of a child is seriously at risk, however, we immediately think about the future and overall long-term dispositions. Semantically, the terms unwell-being and child endangerment are counter-terms to the notion of the well-being of the child. In order to elucidate the concept of well-being itself, the counter-terms are inadequate because of their asymmetry; further insight is therefore needed. But what kind of insight? What can insight achieve?

\section{Generative Insight: A Research Perspective}

We have pointed out that a description of the well-being of the child in concrete contexts needs both an objective (third person) and a subjective (first person) perspective. Wellbeing is not established by causal relations between a subject and objects, but is embedded in a relational structure of intentions and feelings, values, and norms. Therefore, well-being cannot be determined in an essentialist way. It is founded and lived in social and generative practices. Generative practices concern the experiences of

\footnotetext{
${ }^{3}$ Philipp Ariès (1975) argued that in the Medieval period, the child was treated as a 'miniature adult'; in the 18th century, childhood received a special social and moral status. Jean Jacques Rousseau pronounced the 'age of childhood'. Since the work of Jean Piaget, Lawrence Kohlberg, Carol Gilligan, Joseph Goldstein and others, the understanding of childhood has been heavily influenced by developmental psychology (Zalazo 2013; Mitchell and Ziegler 2012).
} 
and relationships between generations, the upbringing and care of children, support for those in need, and the arrival and passing away of persons who belong to the structure of generativity. We need to focus on the meanings that are established within those practices. The dimension of meanings can be directly examined in a hermeneutic-phenomenological approach to generative relationships, which we call generative insight (Schües 2007, pp. 235-238).

Generativity in reference to the epistemological concept of insight means, on the one hand, the genesis of meaning as a narrative and interpretative process of meaning production. On the other, it means the relational processes between generations, which include a bodily, mental, social, and cultural intertwinement. Insight, as we use it here, is a term that belongs into phenomenological moral philosophy and means the grasping of the salient, essential aspects of a situation, seeing the basic structures of a context of meanings and narratives. Insight is a kind of thinking and perceiving that is opposed to mere beliefs and to detached and abstract argumentation. Its rationality is closely related to what Aristotle described as phronesis or 'practical wisdom'. Generative insight therefore is a procedure of thinking, empathy and perception, which, in regard to a concrete question or problem, grasps the particular content and coloration (including the struggles, tensions, atmospheres) of generative relationships. The question of what the well-being of a child in a concrete situation implies, is a question of moral practice and theory, different from a particularist 'case by case approach'.

This question is important for the people involved in these concrete situations, for how they make sense of them and what they do in practice. It is not merely a topic of research in a general interest. What we want to explain here about the practice of 'insight' is therefore both a strategy for gaining insight for people involved, and a strategy of research in philosophy and anthropology. Bringing up children well, deciding for children in practical matters or problematic situations well, presupposes having insight into the social, generative, and individual conditions and meaning-constitution of well-being.

Insight has two sides: it can be understood in the sense of both 'gaining' insight and 'having' insight. Gaining insight addresses the idea that insight is a dynamic form of knowledge that arises from an interaction of rational criteria and empathy. It is always lived praxis and theoretical observation. Having insight refers to the meaningful context of a concrete theme and its narrative constitution. Insight refrains from immediate judgments about moral prescriptions. It introduces an interval in which clarification can occur. As Paul Ricœur formulated, a narrative of how a situation can be understood and lived is the "first laboratory of a moral judgment" (Ricœur 1990, p. 167, own transl.). That means the way a situation is described and told has a strong influence on how a morally difficult issue is seen and decided upon.

This triad of description, narration, and judgment (Ricœur 1990) is best addressed by a phenomenological approach, because phenomenology is a descriptive science of experiences and a search for the constitution of meanings by asking how they appear and how they are believed and on what basis and prejudices. It is concerned with the structures of experience as they appear to humans in their subjective consciousness and interpretations.

Since the time of Plato, philosophy has distinguished between knowing by empirical facts or cognition and knowing by insight. The first is valuable within a broad concept of philosophical anthropology. The latter refers to grasping the most striking aspects and essential meanings, i.e. the basic meaningful structures of an issue. This distinction is important because, as we have seen, the wellbeing of the child is not an empirical notion but rather a "hypothetical construct" (Dettenborn 2010, 49) which is used in very different contexts, in order to draw attention to the child's perspective and subjectivity. Well-being, child endangerment, or the unwell-being of the child cannot be just empirically determined. The key is to have an idea of which questions to ask and which themes to bring up. Obviously, empirical knowledge of the situations is also necessary for this.

Since the well-being of the child does not depend upon the children themselves but on their good care by the family or carers and on the quality of the relationships and the social context in which they live, a methodological approach is needed to address the generative and social relations that are basic for a child. The concept of generative insight contains the presupposition that every human being is born into, and that therefore everybody lives and has lived within a social and generative relational structure.

The main point in referring to a generative structure is that the child is always seen as a concrete bodily, gendered, culturally situated human being and never abstractly posited in fictive isolation, devoid of human relationships. This understanding of generative insight focuses on the whole generative context and always asks about the welfare of the concrete relationships which are or must be lived by a child.

By reference to different forms of insight, we can address the triad of description, narration, and judgment: a situative function of insight gives a general description of circumstances, a generative function of insight might explicitly address aspects of the generative relationships in a biographical narrative, and a normative function of insight tries to interpret the norms and values involved.

One advantage of such a phenomenological approach to generative insight is that it combines structural thinking with concrete perception. It refers to a child as always 
living in the generative structure that establishes a society, and it tries to analyze the underlying questions and meanings. For this it needs to listen to all voices involved.

Insight also needs time. There are forms of instantaneous insight into a situation that see what one 'must' do now. But there are also forms of more slowly growing insight that need time to get settled and to be developed step by step.

\section{Questions and Themes of the Well-Being and Unwell- Being of a Child}

We assume as a fundamental belief that the well-being of a child is understood and developed with regard to (a) a good life for this child. The regard for the good life, however, implies a sense for (b) justice. Justice implicitly refers to other humans who are (c) in relation to the child. The thematization of the child's development in its generative context and in reference to the 'good life' brings up (d) the underlying temporal dimension of the well-being of a child. The structural relation between these four aspects can be explained in the following way: If we wish that a child is well we must also wish that he or she has a good life. Having a good life means to live in relationships and social institutions that are not characterized by severe injustice. The experience of severe injustice and being unjustly treated is not compatible with living a good life. Justice is a relational term because it takes place between humans. Therefore, for the child's well-being we also need to consider the quality of relations in which the child lives and with which she or he is faced. More than just clarifying the individual child's autonomy and happiness, this situates the child explicitly in a relational and generative context. Since the well-being is directed toward the good life in the long term, the underlying temporal dimensions need to be discussed.

\subsection{Good Life}

The notion of good life is used to describe a way of life that is desirable. Ursula Wolf (1999; cf. Susan Wolf 1997) insightfully argues, with reference to the Aristotelian notion of eudaimonia, that the notion of the 'good life' cannot be explained through some hedonistic conception of pleasure or a notion of luck but rather in terms of how somebody can and may live in a meaningful way. A good life is a meaningful life. The notion of meaning is understood as a relational structure of self and world (Wolf 1999). Therefore, the question 'what is a good life?' must be reformulated in the sense of how to live a good life and how to help somebody else live a good life. The good life is not a concept like a container in which goods are held; a meaningful way of life is built within structures of relationships and concrete contexts in which sense or meaning can be experienced. Therefore, a good way of life is one that succeeds in being meaningful with regard to oneself and with others. The interpretation of such meaningfulness itself depends upon the other, and reflects back to the experience of life itself.

Hence, the 'meaning of life' is to be found in interpretation. Interpretation is based on the 'inter-relation' of oneself and others, in the description of experiences, in the narration of the lived stories, and in the moral judgment of what seems right or wrong. This interpretative interrelation is addressed by the hermeneutic-phenomenological perspective of generative insight. It is essentially interpretation and the attempt to make sense. It relates practice and theory, experience and meaning, the concrete and the general. Interpretation is part of its meaning constitution. Therefore, to argue that the concept of well-being of a child should be understood and actually lived in regard to a good life, also implies the obligation to support the child in living a meaningful life. This can only be achieved if carers share with the child the different insights they might have into their surrounding world and the stories of which it is made up. The interpretation of well-being in regard to a good life is important also ethically because it influences decision-making practices.

If a child's well-being is harmed, development towards the good life is not furthered. But this is not a simple exclusion. We all know that in life, periods of unwell-being can happen. Illness does not mean that a good life becomes impossible. The unwell-being of a child is not necessarily a sign of bad relationships; poor health or difficult circumstances might not immediately be a sign of child endangerment. Whether or not it may hinder the path to a good life cannot be decided in general terms.

\subsection{Justice}

The well-being of the child is to be found in reference to institutions, their social contexts and relations. If they are unjust, then the child will feel (or is) mistreated and uncared for. Charles Dickens (2003, p. 60) has the orphan Pip say: "My sister's bringing up has made me sensitive. In the little world in which children have their existence, whosoever brings them up, there is nothing so finely perceived and so finely felt, as injustice."

Justice has two sides: legal rights and the ethically right or good. The sense of justice is not to be found in the juridical dimension, yet it is often challenged or changed by it. The idea of justice in an ethical sense is developed in human relationships. From an objective standpoint, relations can be said to be just or unjust, but from a local perspective humans share an acute sense of justice or injustice within their relationships (Moore 1978). 
The notions of justice or injustice refer to institutions and their relational structure. Institutions are historically grown communities, such as nations, religious groups, or families. As Ricoeur pointed out (1990, p. 227), their structure cannot be reduced to individual relations, yet they are based on such relations. Many institutions are based on the equality of their members; they infer justice accordingly, following an egalitarian approach. Yet a 'generative' institution such as a family is based on inequality. Their members need very different kinds of care and intimacy, hence in this context justice has to be based on a nonegalitarian model. But nevertheless, if close carers place a child in a situation of severe injustice, the well-being of the child can be violated; the life of the child in that situation cannot be considered as a good life. Acts of solidarity or help are often considered to be family duties, which would not be considered a duty in other contexts. Thus, for the concept of the child's well-being, the question of justice is closely linked to the meaning and status of generative relationships.

Beside injustice also misfortune is relevant for a child's well-being. Judith Shklar has drawn attention to the conceptual difference between these terms. 'Injust' may be something which is experienced as avoidable and alterable, whereas pure 'misfortune' suggests inevitability and unalterability (Shklar 1990, p. 58). The child's well-being can be reduced or endangered by both but is experienced in different meanings and with different implications for the carers' responsibilities.

\subsection{Relationships}

If it is true that a child (as any other human) is always in relation with others, questions arise about the qualities of such relationships. The quality of a relationship should be understood specifically in regard to the well-being of the child. The child cannot choose the relationships or the family s/he wants to live in. A child is born into them (Schües 2008, p. 445ff.). Therefore, generative insight into the relational structures and an ethics of relationships are key for clarifying the concept of well-being. Any child will live in more or less close relationships. Children live in families, in an intergenerational and a wider social context.

If the quality of generative relationships is too poor, we can speak of the child's well-being as endangered. The familial relation is a specific we-relation (Husserl 1973, p. 428ff.), characterized by a particular "generative density" (Steinbock 1995, p. 215). In terms of the family, each member is identified as one part. A sister would not be a sister without a sibling. At their best, familial relationships are characterized by trust, care, intimacy, participation, the readiness to stand by each other in difficult situations and as a last recourse. A meaningful life needs other humans who together constitute concrete, meaningful experiences and relationships (Schües 2012, p. 98). The familial relation cannot be reduced to individual relationships, say between the mother and the daughter, yet the quality of the individual relationships is the basis for the overall relational structure in which a child grows up. Questions concerning the well-being of the child may arise when we ask which tasks a child needs to fulfill because of being part of a family and because of sharing a close familial relationship.

One example is the transplantation of blood stem cells (bone marrow) between siblings as Jodi Picoult vividly describes in her novel My Sister's Keeper (Picoult 2004). Some ethicists have argued that because of intrafamilial obligations family members have responsibilities for one another's welfare, including the duty to donate bone marrow, because they share an "intimate family relation" (Ross 2009, Kesselheim et al. 2009; Committee on Bioethics 2010). The child, according to this approach, has an obligation to help by undergoing the procedure of bone marrow donation, and bears responsibilities for the sibling regardless of his or her own benefit. The normative content of the family relationship is a system of duties; therefore it is presupposed that the donor sees his/her act as one of helping, but not as a violation of his/her interests, inflicted by parents or doctors. But this way of putting the case presumes one perception by the child-whether it perceives the donation as helping the sibling or harming him/ herself. It is a kind of 'proxy perception' by the decisionmaking person who needs to justify proxy consent. "The most plausible justifications for donation by minors are the best-interest standard, the intimate-attachment principle, and the appeal to intrafamilial obligations." (Kesselheim et al. 2009, p. 415) The authors appeal to these three positions because they want to see a donation by "a nonintimate biological sibling" as not justified. ${ }^{4}$ How intimacy is constituted and how far it reaches normatively is however an open question. In a previous paper we have argued against the position that intimacy grounds such duty on the part of a child (Schües and Rehmann-Sutter 2012). We would rather argue that this can be a situation in which the temporary unwell-being of the donor child must be accepted, with regret. The only choices are either having a child who dies or taking the chance of a cure, and this cure implies the injury and temporary unwell-being of the donor child. The question of whether this is child endangerment

\footnotetext{
${ }^{4}$ Lainie Friedman Ross (2009) agrees with the argument from intimacy but claims that the question of whether a particular child is an appropriate donor should be discussed before HLA testing and that such children should have an advocate. In his response, Kesselheim (2009) reemphasizes the primacy of parents' decision making and the problematic length of time when debates come before the individual testing.
} 
or just a kind of unwell-being will actually be decided within the specific qualities and meanings of the family relations, which include empathy and the justifications given to the child. The question is: How can they live with it? Can they live with it well? And how will they cope?

If the quality of the relationships is poor, or a child is maltreated, well-being is endangered. The ruin lies in the broken trust, in violence or in the violation of integrity, as well as in the perceived meaninglessness of life decisions and the path of life. Violence cannot be undone by interpreting it differently, by talking it away for example by saying: "the slap in your face was only for your own good". However, the interpretations and narratives parents use, for instance before and after a bone marrow transplantation, are crucially important to the well-being of the child and its development in regard of a good life.

\subsection{Temporality}

Development towards a good life is essentially temporal. It is always about the future. Questions of the good life involve several temporal aspects. The question of how we want to live is related to the questions of how we like to spend our time (Rosa 2005) and how should children spend their time. What activities, spaces, contexts, and relationships are suitable for children? Childhood as a phase of life passes quickly. This time, and the time thereafter, can be spent in a more or less meaningful way. Thus, it may be that children have to find their own path of life that makes sense to them.

If one associates the well-being of the child with the idea of a good life and with the wish of the parents or caregivers for the children to have a good life in the future, then the question must be posed of how the future is perceived. Joel Feinberg's well-known concept of "the child's right to an open future" (Feinberg 1980; Davis 1997, 2009) does not adequately explain the future dimension of wellbeing. He argues that it is important that one keeps children's future open. If one understands him to mean that parents should not predetermine the child's life in a very strict sense, that they should not interfere physically into body shape, we would agree. However, if well-being is directed towards a good life in the sense of having a good future, a more complex appreciation of the relationship between present and future seems necessary. A good future is not merely an open future. Education, knowledge, emotional, esthetic and ethical formation result in making possible (enabling) certain paths of life and preventing others. To take an example: most parents wish that the upbringing they give their child does not lead to the life path of a criminal or an alcoholic. Parents support the development of a strong character in their children in order to make sure that later on they will successfully find their appropriate life path. Finding the balance between strengthening the character, giving guidance to a certain desired path, and leaving the future open in certain respects, needs concrete generative insight. Children need a kind of guidance that enables their future competence to decide by themselves. Their whole good life is at stake in the present.

\section{Conclusion}

The concepts of autonomy and happiness are certainly too thin to account for all the ethically important contents of the well-being of the child. We have tackled the well-being of the child as bordered by the counter-terms of child endangerment and the unwell-being of the child. Yet we have argued that it is not possible to isolate in any convincing way an essential, universal meaning of well-being. Autonomy and happiness cannot do this job; any kind of pre-determined definition fails to account for the social, cultural, or individual heterogeneity and complexity contained in the idea of a child's well-being. Nevertheless, insight into concrete issues and contexts, and insight into what people understand and perceive as the well-being of the child, have an important impact on decision-making and practice with regard to children.

The method of clarifying the concept of the well-being of the child and the path of constituting its meaning are intertwined and need continuous explanation. Insight into the well-being of children is generative, insofar as it is a concept which is embedded in a sense of genesis, based in a temporal dimension, and directed towards the good life as a meaningful life, sensitive to the justice of the relational structure and the social context, and to the quality of the relationships themselves. Therefore, the well-being of the child is a relational concept which demands a hermeneuticphenomenological approach for its clarification that we call 'generative insight'. This includes rational criteria as well as empathy. It is both theory and praxis.

Acknowledgments We thank Janice McLaughlin, Thorsten Moos, Lili Schwesinger, Sarah Daubitz and Lina Busch for encouraging discussions. Jackie Leach Scully and Monica Buckland provided textual suggestions that made the argument clearer. The paper originated from a study on the well-being of the child in stem cell transplantation, which is funded by Thyssen Foundation and Karl Peter Ringel.

\section{References}

Alston P, Parker S, Seymour J (eds) (1992) Children rights and the law. Clarendon, Oxford

Ariès P (1975) Geschichte der Kindheit. Hanser, München

Committee on Bioethics (2010) (lead author Ross L F) American Academy of Pediatrics Policy Statement-Children as Hematopoietic Stem Cell Donors, pp 393-404, 394 
Convention on the Rights of the Child (1989) Adopted and opened for signature, ratification and accession by General Assembly resolution 44/25 of 20 November 1989. Entry into force 2 September 1990, in accordance with article 49 http://www2. ohchr.org/english/law/crc.htm

Crisp R (2008) Well-being. Stanford Encyclopedia of Philosophy. http://plato.stanford.edu/entries/well-being/

Davis D (1997) Genetic dilemmas and the child's right to an open future. Hastings Center Rep 27(2):7-14

Davis D (2009) The parental investment factor and the child's right to an open future. Hastings Center Rep 39(2):24-27

Dettenborn H (2010) Kindeswohl und Kinderwille. Psychlogische und rechtliche Aspekte, 3rd edn. Reinhardt, München

Dickens C (2003) Great expectations. Barnes \& Noble Classics, New York

Feinberg J (1980) The child's right to an open future. In: Aiken W, LaFollette $\mathrm{H}$ (ed) Whose child? Children's rights, parental authority and state power. Littlefield, Adams \& Co., Totowa, pp 124-153

Figdor H (2009a) Im Namen des Kindes. Zur Kritik herkömmlicher Sachverständigen-Praxis aus psychoanalytisch-pädagogischer Sicht. In: Datler W, Finger-Trescher, U Gstach J et al (eds) Jahrbuch für Psychoanalytische Pädagogik 16. PsychosozialVerlag, Gießen

Hagger L (2009) The child as vulnerable patient. Protection and Empowerment, Ashgate

Husserl E (1973) Zur Phänomenologie der Intersubjektivität. Texte aus dem Nachlass, Dritter Teil: 1929-1935. In Kern I (ed) Husserliana, vol. 15. Nijhoff, Den Hague

Kesselheim JC (2009) Reply to Ross, LF: the ethics of hematopoietic stem cell donation by minors. In Archives of pediatrics \& adolescent medicine, vol 163 (11), Chicago, p 1066

Kesselheim JC, Lehmann LE et al (2009) Is blood thicker than water? Ethics of hematopoietic stem cell donation by biological siblings of adopted children. Arch Pediatr Adolesc Med 163(5):413-416

Lempp R (1983) Gerichtliche Kinderpsychiatrie und Jugendpsychiatrie. Huber, Bern

Merleau-Ponty M (1962) Phenomenology of perception. Routledge \& Kegan, London

Mitchell P, Ziegler F (2012) Fundamentals of developmental psychology, 2nd edn. Psychology Pr, Milton Park

Moore B (1978) The social basis of obedience and revolt. Macmillan, London

Nussbaum MC (2011) Creating capabilities. The human development approach. Harvard University Press, Harvard

Picoult J (2004) My sister's keeper. Hodder \& Stoughton, London

President's Commission for the Study of Ethical Problems in Medicine and Biomedical and Behavioral Research (1983)
Deciding to forego life-sustaining treatment. A report on the ethical, medical, and legal issues in treatment decisions. Washington

Rehmann-Sutter C (2012) Können und wünschen können. In: Eilers M, Grüber K, Rehmann-Sutter C (eds) Verbesserte Körpergutes Leben? Bioethik. Enhancement und die Disability Studies, Lang, Frankfurt/Main, pp 63-86

Ricœur P (1990) Soi-même comme un autre. du Seuil, Paris

Rosa H (2005) Beschleunigung. Die Veränderung der Zeitstrukturen in der Moderne, Suhrkamp, Frankfurt/Main

Rosenheim MK, Zimring FE, Tanenhaus DS et al (eds) (2002) A centure of juvenile justice. University of Chicago Press, Chicago

Ross LF (2009) The ethics of hematopoietic stem cell donation by minors. Arch Pediatr Adolesc Med 163:1065-1066

Schickhardt C (2012) Kinderethik. Der moralische Status und die Rechte der Kinder, Mentis, Paderborn

Schües C (2007) The contemplative conditions of a moral action. In: Fielding H, Hiltmann G, Olkoswski D (eds) The other. Feminist reflection in ethics. Palgrave MacMillan, Basingstoke, pp 227245

Schües C (2008) Philosophie des Geborenseins. Alber, Freiburg

Schües C (2012) Was gibt der Generativität Sinn? Über Geburt, Zeit und Narrativität. In: Shchyttsova T (ed) Intergenerative Erfahrung. Bautz, Nordhausen, pp 89-107

Schües C (2013) Kindeswohl. In: Kapust A, Gröschner R, Lembcke O (eds) Handbuch der Würde, Handbuch Menschenwürde. Suhrkamp, Frankfurt/Main

Schües C, Rehmann-Sutter C (2012) Hat ein Kind eine Pflicht, Blutstammzellen für ein krankes Geschwisterkind zu spenden? Ethik Med (online first Mai 2012: doi:10.1007/s00481-0120202-z)

Shklar J (1990) The faces of injustice. Yale University Press, Yale

Siep L (1994) Ethik und Anthropologie. In: Barkhaus A, Mayer M, Roughley $\mathrm{N}$ et al (eds) Identität, Leiblichkeit, Normativität. Neue Horizonte anthropologischen Denkens, Suhrkamp, Frankfurt/Main, pp 274-298

Steinbock A (1995) Home and beyond. Generative phenomenology after Husserl. Northwestern University Press, Evanston

Steindorff C (ed) (1994) Vom Kindeswohl zu den Kindesrechten. Luchterhand, Neuwied

Wolf S (1997) Happiness and meaning: Two aspects of the good life. Soc Philos Policy 14:207-225

Wolf U (1999) Die Philosophie und die Frage nach dem guten Leben. Rowohlt, Reinbek

Zalazo PD (ed) (2013) The Oxford handbook of developmental psychology, vol 2. Oxford University Press, Oxford 